\title{
Religiosity and Socio-Ecological Spirituality of Indonesian Community According to Y. B. Mangunwijaya
}

\author{
C. B. Mulyatno \\ Universitas Sanata Dharma Yogyakarta, Indonesia \\ Email: carlomul@gmail.com
}

\begin{abstract}
This study aims to explore the thoughts of Y.B. Mangunwijaya on religiosity and socioecological spirituality. By using descriptive-inventive methods and character studies, this research focuses on exploring the ideas of Y.B. Mangunwijaya about religiosity and socio-ecological spirituality rooted in the context of Indonesian society. This study finds an important idea that religiosity is the thrill of every individual in living together in the midst of this universe. Meanwhile, spirituality is the driving force in each individual to work together in developing the quality of life in the midst of a sustainable nature. Religiosity and spirituality are at the core of the experience of religious life. Various groups and local communities of the pluralistic Indonesian society have inherited religiosity and spirituality which includes self-awareness as part of nature sensitivity to various natural problems, competence or skills to maintain the environment and social responsibility to cooperate in developing environmental conservation movements. These four things need to be developed as a point for parties to build unity and cooperation among community members. This idea is a contribution and inspiration to develop the ecoliteracy movement in the community and in the family.
\end{abstract}

Keywords: Indonesian Identity, Pluralism, Solidarity, Caring, Socio-Ecological Responsibility, Environmental Preservation.

\section{A. INTRODUCTION}

One of the distinctive characteristics of Indonesian society is the depth and richness of religiosity which has a major influence on the praxis of life. Relationships between humans and the natural environment are based on and inspired by a belief in the divine power that plays a role in the history of life. In the political field, religiosity has a major influence on the model and practice of leadership. Religiosity is influential in understanding the meaning and living the meaning of welfare. Religiosity also affects the praxis of community life and education in the family and society. It can be said that Indonesia is a very religious nation.

In the midst of the globalization of information, people live in a very close relationship. However, the connectedness is more horizontal in character and tends to leave the vertical connection, namely the human relationship with Allah. Horizontal relationships also tend to be anthropocentric, centered on human pragmatic interests, and instrumentalistic towards nature (making nature a tool to meet human needs). The pragmatic-instrumentalistic mentality is the driving force for blindly exploitative behavior towards nature. The pragmatic-instrumentalistic mentality, which is supported by the development of technology and industry, 
which is oriented towards maximizing profits, has further exacerbated the destruction of nature and the environment. In other words, pragmatic individual interests for short-term interests have eroded religious and socio-ecological awareness and attitudes.

In the midst of the threat of natural destruction which is also a threat to the destruction of human life, there are many movements that respond to it. Various seminars on the dangers of environmental damage have been conducted. There are many nature conservation movements such as river conservation, organic waste processing, conservation of various types of endangered animals, planting of mangroves on the beach, and the development of organic agriculture. Schools of nature began to be developed in various places. Several religious leaders loudly proclaimed the importance of ecological repentance, a movement to reform attitudes and behaviors that have an impact on concrete efforts to preserve the environment.

Y.B. Mangunwijaya (1929-1999) was a humanitarian fighter who was very concerned about environmental conservation. For him, environmental preservation is the need and responsibility of every individual for the development of himself as a whole as a religious being. Solidarity in living together and concern for preserving the environment is rooted in religious awareness passed down from generation to generation in Indonesian society.

This paper focuses on exploring the thoughts of Y.B. Mangunwijaya about religiosity and socio-ecological spirituality which is the basis for efforts to preserve the environment. This is the first research on religiosity and ecological spirituality based on the thoughts of Y.B. Mangunwijaya. So far, the same research has never been done.

\section{B. METHOD}

This study uses a qualitative method (Sugiyono, 2012). The qualitative method applied in this research can also be referred to as a qualitative method of literature study or written documents because the main source of this research is the library data produced by Y.B. Mangunwijaya. The literature study was chosen based on the consideration that the character whose thoughts were studied had died so that the source of the literature was the clearest data that could be accounted for.

This research can also be categorized as character research $(\mathrm{H}$. Arief Furchan and H. Agus Maimun, 2005). The research subject is Y.B. Mangunwijaya. According to the theory of character study research, there are three steps of data analysis that need attention. First, the thoughts of the characters need to be analyzed based on the dimensions of a particular scientific field. This is important in order to find the characteristics of the character's thinking. Second, it is necessary to find basic ideas that connect various themes or fields of thought of the character and his humanitarian activities in the social context of his time. Third, the researcher classifies the character's thoughts into scientific fields. The scientific field that becomes a tool for analyzing data is environmental and cultural philosophy. 
Studying religiosity and ecological spirituality is very important in the midst of the diversity of culture, ethnicity, ethnicity, race, religion and belief that is widespread in Indonesia. Ecological religiosity and spirituality are the basis for building awareness, responsibility and joint movement of the Indonesian people to preserve the environment as an integral part of cultural preservation and development of the nation's life. This study aims to explore the richness of religious values and social-social-ecological spirituality of the Indonesian nation based on the thoughts of Y.B. Mangunwijaya.

This research has two benefits. First, this research is useful to raise socioecological religiosity and spirituality which is rooted in Indonesian culture. Second, socio-ecological religiosity and spirituality became the basis of a joint movement to preserve the environment in the midst of various environmental crises that hit the world.

\section{RESULT}

Research results related to religiosity and ecological spirituality based on the life and work of Y.B. Mangunwijaya covers three important things. First, ecological religiosity and spirituality appear in Y.B.'s humanitarian work. Mangunwijaya. That is, the humanitarian work of Y.B. Mangunwijaya contains an ecological vision. Second, the ecological vision is revealed in the notion of an integral human being. Third, in the books he wrote, Y.B. Mangunwijaya explicitly emphasized the importance of cultivating ecological religiosity and spirituality.

\section{Humanitarian Work with Ecological Vision}

Y.B. Mangunwijaya is known as a fighter for humanity and a friend of the poor. His concern for the service of the poor became widely known when he chose to live with the poor in the Code River valley from 1980 to 1986. The choice to live with the poor received the blessing of Cardinal Darmajuwono, the Archbishop of Semarang. Together with people who come from various regions and live in the Kali Code bees, Y.B. Mangunwijaya organizes the area to make it more beautiful, healthy and humane. As an architect who really values culture, he builds simple houses made of wood and bamboo that are environmentally friendly.

Y.B. Mangunwijaya received the Aga Khan Award for architectural works in the Kali Code valley area. This confirms the international recognition of his character. The authority of Y.B. Mangunwijaya in the field of architecture is recognized at home and abroad for his support for the defense of the poor and the preservation of culture and the environment. The preservation of the environment and culture is guaranteed by the development of the quality of education, increasing the level of welfare, and the development of cooperation or mutual cooperation between citizens. Based on the testimony of Mr. Eko, a resident of the Code River valley who fought with YB. Mangunwijaya, community cooperation was developed by YB. Mangunwijaya through three activities or Tribina, namely human development, environmental development and economic development. The struggle 
to improve the quality of human life is marked by the realization of economic prosperity and the preservation of the environment. This is what is meant by the humanitarian struggle with an ecological vision.

After the people of the Code River valley began to progress and become independent and received great attention from the wider community to continue Tribina, Y.B. Mangunwijaya decided to leave the community there. Attention Y.B. Mangunwijaya towards the poor and especially the victims of injustice is directed at the community victims of the construction of the Keduk Ombo dam, Central Java from 1986 to 1994. Basic education for children, assistance to grow people to realize their rights as citizens and improve welfare the economy is the main concern $\mathrm{YB}$ Mangunwijaya in his struggle with the victims of the construction of the Kedung Ombo dam. Voicing and defending justice is the duty of every citizen because every individual has the same dignity.

In addition to directly defending and assisting the poor in the area around the Kedung Ombo reservoir project in Sragen during the New Order era, Y.B. Mangunwijaya also assists the poor in Grigak, Panggang-Gunung Kidul who experience drought every year. He is looking for a way to lift water from the coastal cliffs of Grigak to overcome the scarcity of water needs of the poor. The community is invited to protect their natural wealth so that they do not become victims of the greed of the owners of capital who can control the water source for their personal interests.

To break the chain of poverty, the education of poor children is very important. They have the right to get a good education so they can build a better future and be involved in developing the nation. They need to be equipped with strong character, creativity and solidarity so that they can help each other to defend their dignity. Assisted by many students and young volunteers, Y.B. Mangunwijaya accompanies and educates poor children. However, he realized that non-formal education is no guarantee of sustainability. Volunteers can come and go at any time. For this reason, he pioneered the work of basic education by turning Kanisius Mangunan School into an experimental school.

Building quality basic education is a way to equip the future of most Indonesian children in developing the basics of a human and dignified life (Tri Hartono, 2001). That means preparing a better future for the nation. Most Indonesian children still live in poverty. Thinking about education and the future of the nation means having to care about the development of quality education for poor children. The Basic Education Dynamics Foundation, which was initiated in 1987, is a vehicle to develop quality basic education that is pro-poor children. Kanisius Mangunan Elementary School which was almost dead was used as a laboratory to develop liberating basic education.

In line with Paulo Freire's educational struggles in Brazil, YB. Mangunwijaya underlined that the educational process should be more liberating. This liberating education provides a place for students to explore themselves as a whole and express their creativity actively. Education is a means for humans that must be 
directed towards the development of human dignity and qualities. So, first of all, the direction of education is the development of "character, world of attitude, piety, mental, spiritual" (Y.B. Mangunwijaya, 2020 [2]). A strong character is the basis for developing personal qualities that have socio-ecological responsibilities in living together who love each other and are involved in preserving the environment.

In addition to attending and living with the poor, Y. B. Mangunwijaya also shows his defense of human dignity through literary and architectural works (Utomo, 1999). In his writings, he raises social issues. He had been a drama director with the title "rat wirok". In 1978, he wrote a short story entitled "corporal Tohir" and the book Ragawidya (Phenomenological-religious reflections on daily life) which in 1992 had been reprinted four times by the publisher Kanisius. In 1975, he received an award in the short story short story competition for the Radio Nederland Indonesian Language Program (Mangunwijaya, 2020).

Since undergoing studies as a candidate for priest at the Kotabaru Seminary, YB. Mangunwijaya has shown his talent as a writer and literature (Utomo, 1999). In his writings he raises social issues. He was once the director of a drama staged by prospective priests under the title "rat wirok". In 1978, he wrote a short story entitled "corporal Tohir" and the book Ragawidya (Phenomenological-religious reflections on daily life) which in 1992 had been reprinted 4 times by the publisher Kanisius. In 1975, he was awarded an award in the short story short story competition in the Radio Nederland Indonesian Language Program (Priyanahadi, 1999).

For Mangunwijaya, literature is an articulation of humanitarian issues and an effort to defend human dignity. Arya's works in the field of literature have contributed greatly to the development of a humanist culture that upholds dialogue, equality, cooperation, and the defense of human dignity. Literature and religiosity are two aspects that cannot be separated because the process of human life and culture in this world is in divine power (Parakitri, 1995). Through literature, he emphasizes the recognition of Allah omnipotence and the gift of life that encourages him to develop himself dynamically in unity with others and the universe.

Literature and culture contain universal values that encourage us to fight for a common life that loves, respects and upholds the dignity of human life. Mangunwijaya emphasized that life is a noble task and a loving call given by the most merciful Allah. Life is a duty to develop brotherhood with others and preserve the universe as a friend who helps humans to live with dignity (Mangunwijaya, 1999).

YB talent. Mangunwijaya in the fields of engineering and natural sciences has been seen since he was a child. When playing with his younger siblings, he uses sand and soil to make toys designed for Dutch and European houses. Talent in engineering and natural sciences began to develop very well in the educational process at Jetis Technical School Yogyakarta from 1942 graduated in 1947. Although his focus of study was interrupted by the war of independence, his great interest in engineering and natural sciences encouraged him to study a lot. Interest in the field of architecture began to grow. 
Mgr. Soegijapranata recognized YB. Mangunwijaya's talent in engineering so that he was prepared to play a role in developing the faith of the people through the construction of places of worship with an indigenous image. Mgr. Soegijapranata sent Mangun to study architect at ITB and then in 1960 sent Mangun to continue his studies in Aachen Germany. Mangunwijaya's architectural vision is strongly influenced by Professor Steinbach who respects local culture and human values. In 1966, Mangun completed his architectural studies from Germany.

The architectural works produced are the Sendangsono pilgrimage complex (Kulon Progo), the Bentara Budaya-Kompas Gramedia Jakarta building, the JetisYogyakarta Catholic church building, the Maria Assumpta Catholic church in Klaten, the Kowilhan II Headquarters, the Hermitage of the Unitary Mother Gedono-Salatiga, Arief's residence. Budiman (Salatiga), Mangunwijaya's private residence in Gang Kuwera, Mrican-Yogyakarta, and a residence for the poor in Code Valley, Yogyakarta.

YB's architectural vision. Mangunwijaya was written in a book entitled Wastu Citra which was published by the publisher Gramedia in 1970. This book became a teaching material at the Faculty of Engineering, Gajah Mada University, Yogyakarta. Wastu Citra contains the meaning and significance of human creative power in fighting for the truth and goodness of this life's pilgrimage so that his image radiates truth, goodness and beauty. For YB Mangunwijaya, architectural works must contain messages and human values, namely the integration of the building with the realities of life and cultural values around the building. The architectural works of Y.B. Mangunwijaya emphasized his side with the poor and the preservation of local culture. The construction of houses and all means of life should consider solidarity and sensitivity to others and the environment. The architectural model is a strong critique of the tendency to build houses and public facilities modeled after skyscrapers, majestic and far from local cultural values. Skyscrapers are increasingly mushrooming increasingly emphasize the gap between those who are rich and those who are poor.

Through literature, architecture, interfaith dialogue, basic education, defense of the poor, and culture, Y.B. Mangunwijaya affirmed his commitment to fulfill the independence of the nation and defend human dignity. There is an important expression that animates his struggle: "Jadilah dulu manusia yang baik, manusia yang manusiawi, lewat kemanusiawian itulah jalan menuju ke Allah (Be first a good human being, a human person, through humanity is the way to Allah") (Mangunwijaya, 1999). "Be first a good human being, a human person, through humanity is the way to God" (Mangunwijaya, 1999). This phrase describes YB Mangunwijaya's religious vision in defending human dignity. The choice to live close to the poor is not a hobby but a call to defend the dignity of fellow human beings as God's creation who must love and help each other. For him, this is the reason YB Mangunwijaya: "In Asia, especially in Indonesia, humans are small, weak, poor, generally not respected. What is appreciated are those who are rich and powerful; who can practically govern whatever they like' (Mangunwijaya, 1999). Even though, the Indonesian nation is 
based on Pancasila, one of which emphasizes the ideal of building a just humanity. and civilized, small and poor communities are often excluded and experience unfair treatment.

\section{Socio-ecological Vision in the Idea of the Integral Man}

Y.B. Mangunwijaya believes that humans are Allah's creation as an integral person (Mangunwijaya, 1999). It is able to develop (bloom) dynamically in unity with the Creator, fellow human beings and the universe. The dynamics of development occur in a complete and organic manner. Humans are individuals with a religious dimension, namely conscientious in developing ideas, determining attitudes and behaving. Humans are natural-social beings who live naturally in the midst of their geographical environment and the society in which they grow. Humans are conservationists and creators of culture, namely living in local traditions and wisdom with the noble values they believe in. Humans have a rational dimension, namely the ability to reason creatively to find alternatives and novelty. Human strength is also seen in the emotional-affective dimension which makes it possible to feel and build a warm bond of living together. In addition, humans also have an aesthetic dimension that manages life colored by the power of imagination and love of beauty. All efforts and struggles of human life lead to the realization of a moral life, namely a life of value, dignity and happiness in the world and the hereafter.

Every individual who has multi-dimensional potential needs other people to be able to help each other and expand or develop themselves in an integral and optimal way. Living together is a field for preserving values and educational interactions that develop insights, attitudes, skills, and behaviors for the good of living together and their environment.

In order for humans to develop integrally and optimally, humans need lifelong informal, non-formal and informal education. YB. Mangunwijaya emphasizes the role of family, community and school education to develop an attitude of piety for each individual to Allah, the Creator. Every individual has the same sublime dignity as Allah's creation and is responsible for developing himself fully and optimally in cooperation and mutual assistance. The universe is a friend who helps humans to live with dignity and love Allah, the Creator. For that, humans are responsible for the preservation of nature. Education helps humans to increasingly uphold the great things and at the same time appreciate the small and trivial as part of the process of human life in the midst of this universe towards the Creator.

In the pilgrimage of life in this world, humans struggle to build a prosperous life with all the talents they have but must still realize that everything they strive for and material things are temporary in the process of experiencing Allah who transcends space and time. Just as Allah loves and cares for humans and His created nature, devotional love for Allah is manifested in an attitude of caring for others, especially the weak and caring for the environment as a home for sustainable living 
together. Living with mutual respect and responsibility for preserving the environment is a tangible manifestation of respect for the Creator.

Diversity is an experience that essentially shapes Indonesian identity since Indonesia has not been recognized as a country. Those who struggle to prepare for Indonesian independence are people who from the beginning lived in a relationship experience with backgrounds of differences and diversity of religion (belief), race, ethnicity, skin color, and language in the context of thousands of islands, traditions, rituals, myths, legends. , symbolism of buildings, crops, and flora and fauna.

For the people of Indonesia, diversity is a unique value and is one of the identities of the Indonesian nation. First, the diversity of Indonesia is a natural gift (without being designed) that has existed since before the formation of the Indonesian state. In this sense, diversity is the wealth of Indonesian society. Second, Indonesian people are diverse in terms of life experiences, culture, language, race, ethnicity, language, beliefs, traditions, and various symbolic expressions. All of them contain values that animate the dynamics of living together with different styles. Therefore, in the value of diversity, there are human values that are very rich and deserve to be explored and preserved. In other words, diversity is Indonesia's human value which is the identity of the Indonesian nation and culture.

Appreciating and giving space to each individual to contribute to togetherness is a form of social justice. Social justice is a human value based on the belief that every member of the community needs each other in togetherness as social beings (Kaelan, 2002). Living in harmony and peace is the need of every individual in living together in society. Every individual is responsible for creating a harmonious and peaceful society. Social justice for all Indonesian people can only be realized when each person is responsible for helping each other meet the needs of life in all its dimensions (Kaelan, 2002). As every individual is multidimensional in character, development and fulfillment of needs are integrally multidimensional.

The reality of diversity that is dynamically lived by the Indonesian people in their interactions with other nations in this global era contains a constant invitation to discover the core of Indonesia's humanity. For YB. Mangunwijaya, the essence of humanity is religiosity. For this reason, religious awareness needs to be continuously instilled in the future generations of this nation.

\section{The Importance of Cultivating Socio-ecological Religiosity and Spirituality}

Religiosity is one of the human aspects in the form of vibrancy and human qualities that encourage the growth of attitudes or tendencies in life (Mangunwijaya, 2020). Religiosity is a fundamental or essential thing in human life. In another sense, religiosity is the inner human forces that exist in the depths of the heart (Sudiarja, 2006). Religiosity is "the mother of love for the truth, liking for symptoms that are natural, simple, honest and true" (Mangunwijaya, 2020).

Religiosity is the core and power of religion. It can be likened that religion is a beautiful flower petal, religiosity is the essence of a flower that lies in the heart of the flower. Religion or religion (Latin: religio, re-legere) is a model of life that is 
characterized by the bond or connectedness of the practice of prayer-ritual life, fraternal community, and acts of charity (Sudiarja, 2006). Thus, religiosity and religion (religion) are two sides of a life model that unites empirical and metaempirical aspects or unites two human sides, namely the physical and spiritual. When religion is not based on inner qualities or religiosity, it loses power and will become just a socio-political activity without a complete human vision. Meanwhile, religiosity without religion will become a charismatic movement whose sustainability and sustainability cannot be guaranteed.

The religiosity that is believed and lived will become a religious attitude and then become spirituality or the driving force to build life together and preserve the environment. In religious traditions, spirituality grows on the basis of the teachings of the Bible, the practice of religious life in rituals, efforts to spread teachings, and various charitable actions. Spirituality or integral human potential that encourages them to live a unique choice and way of life as a form of witnessing and proclaiming religious values such as love, brotherhood, peace, concern for the poor, education for the younger generation and environmental conservation. life. The form of spirituality is morality or good actions that are done repeatedly so that it becomes a good tradition.

Indonesian society has a diversity of religions, cultures, and religiosity which are closely related to mysticism or the experience of human relations with the transcendent that goes beyond the descriptive and analytical language of science. Mysticism is the core or spirit or fire of religiosity, namely the experience of human relations with the divine (the transcendent) which is the basis for understanding and living the reality of life in this world (O'Collins \& Farrugia, 1996; Inchody, 2003). In other words, mysticism develops in the local social and cultural context. The wealth of mystical experiences of various religious adherents is a capital to enrich each other in interaction and dialogue. Various mystical experiences from adherents of different religions are increasingly becoming wealth and capital to build a life together in religion and find concrete cooperation movements in managing life together.

In line with Teilhard de Chardin's view, Y.B. Mangunwijaya emphasized the importance of exploring socio-ecological spirituality or religious values that link mystical experiences with socio-ecological responsibilities to build a peaceful life in a sustainable environment (de Chardin, 1971). This socio-ecological spirituality is a capital that brings together adherents of different religions for dialogue for the development of the quality of life together. For Chardin, socio-ecological spirituality needs to be grown based on human experience, namely "oneness with God, oneness with the world and oneness with God through the world" (de Chardin, 1968). Conservation of nature and the environment is the responsibility of religious adherents and all human beings who live in togetherness as Allah's creation in the midst of their environment (Inchody, 2003).

Spirituality that grows on the basis of the experience of human relations with Allah, with the worldly nature and through the worldly nature, fosters religious 
attitudes. Adherents of any religion are creatures of Allah who live and are responsible for developing the quality of life together in the midst of the threat of environmental damage today. Therefore, every follower of religion as an integral human must have human attitudes and behaviors that result in peaceful coexistence in a sustainable environment (Mangunwijaya, 1999). Humans recognize the omnipotence and absolute sovereignty of Allah and believe in the socio-ecological responsibility to develop themselves actively and dynamically in unity with the natural surroundings. There is an awareness and belief that life is a noble task and a loving call from Allah, the Wise and Compassionate. This life is not a static fact and an unchangeable fate, but a potential or possibility that still needs to be developed through dialogue and cooperation. Humans live in unity with others and the whole universe who is blessed with the grace of freedom to preserve and preserve it creatively and to use nature for noble purposes according to the will of the Creator.

The universe is a friend who helps humans to live with dignity and love the Creator. The history of human life in the midst of this universe is a process from Allah and for the sake of development towards the goal of fulfilling the promise of the good Allah. For that, humans need to be sensitive to everything that happens in the universe. Thus, humans are increasingly upholding the great things and at the same time respecting the small and trivial as part of their life process in the midst of this universe towards the Creator.

As intelligent beings who live in togetherness, each individual has responsibility for personal and collective life, is firm in principles (not easily carried away), is aware of one's limitations and understands others and cares for those who are weak. The task and responsibility of humans is to build a prosperous life with all the talents they have (a true explorer) but realize that everything they strive for and material things are temporary in the process of experiencing Allah who transcends space and time. The affirmation of human dignity is seen in solidarity and compassion for others and being responsible for living together. However, the struggle to realize prosperity in solidarity and environmental preservation is still based on the awareness of the existence of mortal and immortal life by acknowledging that Allah, the Most Merciful, is involved in both mortal and immortal life.

Socio-ecological spirituality becomes the starting point and meeting point for dialogue to find ways to develop life together in affirming the identity of the Indonesian nation which is plural and rich in biodiversity. Socio-ecological spirituality should be the basis for organizing the fields of politics, economy, education and various public policies (Y.B. Mangunwijaya, 1999[1]). In the midst of the challenges of national disintegration and environmental damage, it is necessary to speak more loudly and be emphasized in various regulations and educational movements to raise awareness and belief that in human life there is a core dimension of religiosity that needs to be developed into an integral spirituality that encourages human action. It is necessary to continue to strive for concrete steps across all fields 
of life to develop socio-social-ecological spirituality in human movements and actions that are integral in everyday life.

There are several important points from socio-ecological spirituality to build a vision and movement for living together in Indonesia. The mysticism of religions in the Indonesian context, local wisdom with an ecological vision, brotherhood in diversity, and socio-ecological responsibility to affirm the plurality of Indonesian identity are meeting points for cooperation and mutual cooperation in developing the quality of life for the children of this nation. The socio-ecological vision and the context of the nation's life become the frame and rope for the effort to transform life together.

First, the responsibility to preserve nature and the environment is a meeting point for citizens with diverse backgrounds in affirming Indonesia's identity as the lungs of the world. Socio-ecological responsibility to preserve ethnic, racial, religious diversity and to preserve biodiversity is the binding rope for building ethical and ecological awareness of the nation's children.

Second, Indonesian people mostly live in the middle of the islands with unique natural wealth. They consist of many tribes and community groups. In order to maintain and emphasize the integral sense of Indonesianness, political policies in the economic, social and cultural fields should really be oriented towards the preservation and meaning of all local wisdom. Culture-based education gets a concrete form when local wisdom with all the values it fights for is truly preserved.

Third, Indonesian people in particular and Asia in general live life as a pilgrimage to a destination. The major religions of Asia teach about life as a pilgrimage. Every year, millions of Muslims make pilgrimages to the holy land of Mecca. Millions of Christians make pilgrimages to holy places. Hindus also know pilgrimage. So are Buddhists. In Javanese society there is a tradition of visiting graves. Pilgrimage is an activity that is driven by inner movement and choice from the heart (Deenabandhu Manchala, 2014). Pilgrimage is an ecological spiritual movement that starts from self-awareness to renew life, leaving negative things in the past, gaining new enthusiasm to build a better life in the future. Pilgrimage is a symbol of the journey of human life who constantly needs to understand his identity, his relationship with Allah, and openness to experience His help and guidance for a better and prosperous life (Manchala, 2014). Human consciousness as a pilgrim is symbolically expressed in various traditional dances and traditional ceremonies. Nyadran and Labuhan ceremonies are concrete forms of traditional celebrations that express human belief that life is a pilgrimage. Pilgrimage activities and traditional pilgrimage ceremonies express the belief that Allah is the ruler of human life and the universe.

In the traditional celebration that expresses the belief in the importance of life renewal in the pilgrimage of life, it is also clearly stated that the responsibility of humans to preserve nature is also clearly stated. Human salvation is marked by a harmonious relationship between humans and Allah and the universe. This belief is also one of the core beliefs of the adherents of major religions. By carrying out 
traditional ceremonies or local wisdom that expresses belief in the pilgrimage of life, adherents of different religions get space for dialogue and renew their relations and commitment to preserve brotherhood and nature conservation.

It can be said that many indigenous religions and major religions in Asia place pilgrimage as an important spirituality. Pilgrimage is a religious attitude that has a relational and dynamic character (Painadath, 2014). Every human being is a pilgrim. It comes from the Creator and goes to the Creator. The dynamic spirituality of pilgrimage is a finding point for various adherents of different religions to build a harmonious, just and brotherly life together so that they can help each other in living a life of pilgrimage in peace and happiness. Relationships and dialogues between followers of different religions and between human beings as pilgrims are increasingly qualified when in this pilgrimage of life each person truly lives his responsibility to preserve nature and maintain harmony. In the dialogue, awareness and responsibility are also built to realize justice and awareness as part of the human community as a creation of the same Allah (Painadath, 2014).

Pilgrimage contains educational aspects, in the process of pilgrimage together as children of the nation who are awarded a rich heritage of various cultures, ethnicities, religions, islands, races and languages, every child of the nation has the responsibility to preserve and develop the heritage of Indonesia. Thus, the pilgrimage process for the affirmation of Indonesian identity contains three aspects of dialogue, namely informative, formative and transformative. Every individual needs to build openness and willingness to inform the wealth of local wisdom and life experiences and openness to listen to information from other individuals. This informative, reciprocal dialogue is a prerequisite for building togetherness and brotherhood that respect and enrich one another. Second, informative dialogue is the basis towards formative. This means that various information about the richness of culture, ethnicity, race, religion, islands and languages aims to build and integrate national awareness and spirit. Understanding differences is not to confront and create animosity (rivalry) but to unite and foster pride in diversity that needs to be conserved responsibly. The pride of the nation's identity in diversity is a bond of solidarity to fight all forms of attitudes and actions that divide the unity of the nation. Thus, transformative personalities who are patriotic, sporty, loyal and responsible for the progress of the nation are born.

One of the legacies of the people of Indonesia and Asia is religious intelligence (genius). Life is lived in relationships with others, nature and God (Inchody, 2003). Sensitivity to the rights and necessities of life of fellow creatures is a natural part of human consciousness. All creatures have the right to live and thrive in the midst of this nature (Kopnina \& Gjerris, 2015). Humans develop an ethical responsibility to maintain harmony and the preservation of nature. In the natural process, Indonesian religions and cultures bequeath an integral and dynamic vision of life. The process of human life is a manifestation (embodiment) of a reciprocal and integral relationship between himself and others, nature and Allah. All life events are influenced by nature and Allah and affect nature and the integrity of life. An 
integral ecological vision has implications for life at large, including in understanding education. Life is a pilgrimage that is educational. Education takes place in the praxis of social life with all the appreciation of traditional heritage. Family and society are the most important places for education. Management of formal education should be drawn from the ecological vision of life.

In the context of Indonesian society which is multi-cultural, linguistic, religious, creed, ethnic, tribal, and local wisdom, education has an important role in preserving diversity, maintaining unity, maintaining harmony, and developing the quality of Indonesianness. Education plays an important role in building the paradigm of thinking, behaving, and behaving as an Indonesian nation. In the context of Indonesia's diversity, uniform education contradicts the context. However, Indonesia also needs a common pattern that can unite. Thus, the educational paradigm itself should unite everything. For example, the paradigm of pluralism is not suitable for Indonesia, which is very rich and dynamic in terms of diversity. Pluralism provides an opportunity to recognize differences in diversity but does not provide space for dialogue-relationships on the reality of diversity. Pluralism emphasizes passive unity in diversity and tends to open up opportunities for each component to simply not interfere with each other. As a result, truth is seen as something relative and/or large groups dominate the small ones, so it is difficult to find common ground that dynamizes the transformation of living together (Mujib \& Rumahuru, 2010). This paradigm has become the basis of religious education in schools to this day.

If you want to develop unity in dynamic dialogue in society, the transformative paradigm of dialogue is an alternative. In this paradigm, the richness of life and dialogue that occurs in society becomes the starting point for the development of society itself (Mujib \& Rumahuru, 2010). Local wisdom or local religious values become the starting point for the driving force (spirituality) of the transformative education of the community itself. The transformative paradigm of community dialogue is the basis for developing transformative education that unites, dynamizes and transforms society in the context of diversity such as Indonesia. This is the basis of the importance of developing religious education which is the basis for the development of democratic individuals. Religious education is important to provide the basis for spirituality and humanism because democracy itself has never had a single meaning (Hans, 1967; Torres, 1998). Mangunwijaya, realizing efforts to develop socio-ecological religiosity and spirituality in humanitarian works and involvement in the struggle to live with the poor in the Code River valley, the victims of the construction of the Kedung Ombo Reservoir and the poor in Grigak, Gunung Kidup, Yogyakarta.

Environmental conservation is a social responsibility based on religious awareness, namely the awareness of humans living harmoniously in unity with all God's creatures. Environmental preservation is an effort to defend dignity and improve the quality of human life in an integral way. These efforts cover four levels, namely self-awareness as an integral part of nature, sensitivity and concern for 
various environmental problems, skills to protect and preserve the environment, and social responsibility to cooperate in developing environmental conservation movements (YB. Mangunwijaya, 1999 and McBride, BB, CA Brewer, AR Berkowitz, and Borrie, 2013). Improving the quality of the four levels, which includes awareness, concern, skills and movement development, is a process of environmental education or ecoliteracy that needs to be implemented continuously.

Environmental awareness and movement need to be developed from an early age in families and schools. In fact, many families and schools have not helped children to care and take concrete actions that foster children's ecological skills. Government policies on education have also not emphasized the importance of environmental conservation. Therefore, environmental education still needs to be emphasized in scientific discourse, public policy and simultaneous implementation in the community so that from an early age children realize that preserving the environment is the responsibility of every human being.

\section{CONCLUSION}

Humans are pilgrims who develop dynamically and integrally. The development has an integral character, namely the unity of the inner-physical aspect. Inner power (religiosity) is revealed in human attitudes and behavior. Humans develop integrally in the sense that humans develop in reciprocal relationships with fellow Allah and nature.

Understanding humans as pilgrims means placing humans as lifelong learners. The development of each individual has an influence on society and its environment. An educational process always has implications for each person's relationship with others and the surrounding environment. Thus, the developments and transformations that occur in the educational process include improving the quality of culture, social life and the environment.

Education in families, communities and schools is not enough to only help to understand diversity. Education is a process to preserve diversity, find values that unite diversity, and fight all forms that undermine unity. Therefore, education must be a praxis of living together that cares, loves, respects each other in real involvement to reduce the number of poor people and preserve the environment. Thus, informal, non-formal and formal education really develops socio-ecological religiosity and spirituality that drives social-ecological responsibility, social solidarity and environmental conservation.

In practice, education needs to provide opportunities and space for children, parents and the community to meet, foster religious awareness, foster socialecological responsibility and work together to take social action together. The mutual cooperation includes activities to help the poor, organize celebrations of national holidays, hold cultural festivals, and maintain the cleanliness and beauty of the environment. Thus, from an early age children experience brotherhood and cooperation in caring for diversity, preserving culture, cultivating social awareness 
and preserving the environment so that a pluralistic Indonesian identity is truly maintained.

\section{REFERENCES}

1. Baker, A. (1986). Metode-metode Filsafat. Jakarta: Gramedia.

2. Chethimattam, J. B. (1998). New Religius Movements and Popular Religiusity", Rethinking New Religious Movements. Roma: Research Center on Cultures and Religions- Pontifical Gregoriana University.

3. de Chardin, P. T. (1971). Christianity and Evolution. London: Collins.

4. de Chardin, P. T. (1968). Letter to Liontine Zonta. London: Collins.

5. Furchan, A. \& Maimun, A. (2005). Studi Tokoh: Metode Penelitian Mengenai Tokoh. Yogyakarta: Pustaka Pelajar.

6. Hans, N. (1967). Comparative Education: A Study of Educational Factors and Traditions, London: Routledge Paperback.

7. Inchody, O. (2003). Asian Religiosity and Theilhard de Chardin: An Exploration into His Cosmic Spirituality. Wodyajyoti, 67(12), 1006-1015.

8. Istanto, F. H. (1999). Arsitektur "Guna dan Citra" Sang Romo Mangun. Dimensi Teknik Arsitektur, 27(2), 40-47.

9. Kaelan, M. S. (2002). Filsafat Pancasila: Pandangan Hidup Bangsa Indonesia. Yogyakarta: Paradigma.

10. Kopnina, H., \& Gjerris, M. (2015). Are Some Animals More Equal than Others? Animal Rights and Deep Ecology in Environmental Education. Canadian Journal of Environmental Education, 20, 108-122.

11. Manchala, D. (2014). Theological reflections on pilgrimage. The Ecumenical Review, 66(2), 139-146.

12. Mangunwijaya, Y. B. (1999). Manusia, Pascamodern, Semesta dan Tuhan: Renungan Filsafat Hidup Manusia Modern. Yogyakarta: Kanisius.

13. Mangunwijaya, Y. B. (1999). Memuliakan Allah, Mengangkat Manusia. Yogyakarta: Kanisius.

14. Mangunwijaya, Y. B. (1999). Gereja Diaspora. Yogyakarta: Kanisius.

15. Mangunwijaya, Y. B. (2020). Menumbuhkan Sikap Religius Anak-Anak. Jakarta: Kompas.

16. Mangunwijaya, Y. B. (2020). Sekolah Merdeka: Pendidikan Pemerdekaan. Jakarta: Kompas.

17. McBride, B. B., Brewer, C. A., Berkowitz, A. R., \& Borrie, W. T. (2013). Environmental literacy, ecological literacy, ecoliteracy: What do we mean and how did we get here?. Ecosphere, 4(5), 1-20.

18. Mujib, I., \& Rumahuru, Y. Z. (2010). Paradigma Transformatif Masyarakat Dialog Membangun Fondasi Dialog Agama-Agama Berbasis Teologi Humanis. Yogyakarta: Pustaka Pelajar.

19. O'Collins, G. \& Farrugia, E. G. (1996). Kamus Teologi. Yogyakarta: Kanisius.

20. Painadath, S. (2014). Spiritual Co-Pilgrims: Toward a Christian Spirituality in Dialogue with Asian Religions. Quezon City: Claretian Publications. 
21. Priyanahadi, Y. B. (1999). YB Mangunwijaya, Pejuang Kemanusiaan. Yogyakarta: Kanisius.

22. Purwatma, M. (ed). Romo Mangun: Imam Bagi Kaum Kecil. Yogyakarta: Kanisius.

23. Sudiarja, A. (2006). Agama (di Zaman) yang Berubah. Yogyakarta: Kanisius.

24. Sugiyono. (2012). Metode Penelitian Kuantitatif Kualitatif dan RED. Bandung: Alfabeta.

25. Sumarthana. (ed.) Mendidik Manusia Merdeka. Yogyakarta: Pustaka Pelajar.

26. Torres, C. A. (1998). Democracy, Education, and Multiculturalism: Dilemas of Citizenship in a Global World. Maryland: Rowman and Litlefield Publishers.

27. Yayhya, I. D. (2005). Romo Mangun Sahabat Kaum Duafa. Yogyakarta: Kanisius. 